\title{
Keanekaragaman dan persebaran lalat buah Tribe Dacini (Diptera: Tephritidae) di Kabupaten Bogor dan sekitarnya
}

\author{
Diversity and distribution of fruit flies Tribe Dacini \\ (Diptera: Tephritidae) in Bogor district and its surrounding area
}

\author{
Anik Larasati, Purnama Hidayat*, Damayanti Buchori \\ Departemen Proteksi Tanaman, Institut Pertanian Bogor \\ Jalan Kamper, Kampus IPB Darmaga, Bogor 16680
}

(diterima April 2013, disetujui Mei 2013)

\begin{abstract}
ABSTRAK
Bogor dan sekitarnya merupakan salah satu wilayah Jawa Barat yang memiliki keanekaragaman tanaman hortikultura yang tinggi dan memengaruhi keberadaan serta keanekaragaman lalat buah di wilayah ini. Penelitian terkait keanekaragaman spesies lalat buah tidak hanya berhubungan dengan jumlah spesies lalat buah, namun juga memberikan informasi ekologi mengenai persebaran lalat buah di Kabupaten Bogor dan sekitarnya. Tujuan dari penelitian ini adalah untuk mengetahui keanekaragaman dan persebaran dari spesies lalat buah serta inangnya di Kabupaten Bogor dan sekitarnya. Lalat buah dikoleksi dari 119 lokasi pengambilan contoh di Kabupaten Bogor dan beberapa lokasi dari Cianjur, Bekasi dan Depok. Pengambilan contoh dilakukan dengan menggunakan 2 metode, yaitu pemeliharaan inang dan penggunaan perangkap. Perangkap yang digunakan adalah modifikasi dari perangkap Lynfield dan dikombinasikan dengan 2 atraktan yang berbeda, yaitu Methyl eugenol (ME) dan Cue lure (CL). Tercatat 18 spesies lalat buah yang didapatkan melalui pemasangan perangkap dan pemeliharaan 24 spesies inang. Hasil penelitan menunjukkan bahwa persebaran, keanekaragaman dan kelimpahan dari lalat buah dipengaruhi oleh keanekaragaman inang lalat.
\end{abstract}

Kata kunci: pemeliharaan inang, Bactrocera sp., perangkap Lynfield

\begin{abstract}
Bogor and its surrounding area is known as one of the region in West Java that has high diversity of horticultural plants that may have an affect on fruit fly diversity. Research on fruit fly diversity is not merely provide information on the species richness of fruit flys but also provide information on its distribution and dispersion. The aim of this research was to investigate the diversity and distribution of fruit flies species and their hosts in Bogor and its surrounding area. Fruit flies were collected from 119 sampling areas in Bogor Cianjur, Bekasi and Depok. Fruit flies were sampled using two methods, i.e. host rearing and trapping. Traps were modified from Lynfield traps and combined with two different attractants, i.e. metil eugenol (ME) and Cue lure (CL). We found 18 species of fruit flies collected from traps and 24 host plants. The result showed that distribution, diversity and abundance of fruit flies was influenced by the diversity of host plants.
\end{abstract}

Key words: host rearing, Bactrocera sp., Lynfield trap

\footnotetext{
*Penulis korespondensi: Purnama Hidayat. Program Studi Entomologi, Departemen Proteksi Tanaman, Institut Pertanian Bogor, Jalan Kamper, Kampus IPB Darmaga, Bogor 16680

Tel: 0251-8629364, Email: purnamahidayat@gmail.com
} 


\section{PENDAHULUAN}

Lalat buah, anggota Famili Tephritidae, Ordo Diptera yang termasuk ke dalam Tribe Dacini terdiri atas 2 genus, yaitu Bactrocera dan Dacus. Di dunia, Bactrocera spp. tersebar di wilayah India, Asia Tenggara hingga wilayah Pasifik, sedangkan Dacus spp. lebih banyak ditemukan di wilayah Afrika (Drew 2004). Di Indonesia, genus Bactrocera tersebar dari wilayah bagian barat hingga Indonesia bagian timur, sedangkan genus Dacus dominan ditemukan di wilayah timur Indonesia (AQIS 2008).

Lalat buah memiliki arti penting dalam budi daya tanaman buah-buahan dan sayuran. Keberadaan lalat buah pada tanaman buah-buahan dan sayuran merupakan kendala agribisnis yang banyak dihadapi oleh petani (Kartini et al. 2003). Kerusakan yang muncul dapat berupa kerusakan secara kualitatif maupun kuantitatif.

Salah satu faktor penting yang mempengaruhi keberadaan dan keanekaragaman lalat buah di Indonesia adalah keberadaan inang yang berperan sebagai sumber makanan (Nishida 1980). Beberapa daerah dengan tipe habitat dan karakter lanskap yang berbeda yang diketahui memiliki keanekaragaman inang lalat buah yang tinggi yang dapat mendukung keanekaragaman spesies dan tingginya populasi lalat buah adalah Kabupaten Bogor dan daerah sekitarnya, seperti Depok, Bekasi dan Cianjur. Selain itu, di wilayah ini juga banyak ditemukan pertanaman komersil yang diketahui sebagai inang dari beberapa spesies lalat buah.

Informasi mengenai taksonomi dan keanekaragaman spesies lalat buah yang tersebar di Indonesia telah dipublikasikan oleh Siwi et al. (2006). Namun, kajian terkait dengan ruang lingkup ekologi dan asosiasinya dengan tanaman inang yang ada di Kabupaten Bogor dan sekitarnya secara khusus masih cukup terbatas. Penelitian ini bertujuan untuk mengetahui keanekaragaman dan persebaran lalat buah serta keanekaragaman tanaman inang yang berasosiasi dengan spesies lalat buah yang terdapat di Kabupaten Bogor dan sekitarnya.

\section{BAHAN DAN METODE}

\section{Area dan waktu pengambilan sampel}

Area sampling pada penelitian ini adalah Kabupaten Bogor dan beberapa wilayah yang berbatasan dengan Kabupaten Bogor secara geografis, yaitu Depok, Cianjur dan Bekasi (Gambar 1), sedangkan berdasarkan ketinggian dan morfologi wilayahnya, area sampling ini terbagi atas beberapa kategori area, yaitu dataran tinggi (501-1.000 m dpl), dataran bergelombang (101-500 m dpl) dan area dataran rendah (50-100 m dpl) (Tabel 1). Pengambilan contoh dilakukan dari bulan Juli 2011 sampai bulan Mei 2012.

\section{Metode pemeliharaan inang}

Pengambilan contoh dilakukan dengan mengumpulkan buah-buahan dan sayuran yang terindikasi terserang lalat buah, yaitu berupa buah yang gugur. Buah dan sayuran yang didapatkan diletakkan dalam wadah plastik yang telah diisi dengan tanah steril dan kemudian ditutup dengan tutup plastik beralas kasa dengan pori kecil. Jumlah tanah yang digunakan adalah sebanyak $1 / 3$ volume wadah. Wadah plastik diletakkan di ruang pemeliharaan dengan suhu yang disesuaikan dengan suhu optimum bagi perkembangan lalat buah, yaitu berkisar antara $27-30{ }^{\circ} \mathrm{C}$. Setelah 1014 hari, pupa lalat buah diambil dan diletakkan di dalam wadah kemudian ditutupi dengan pasir yang telah disterilisasi. Wadah yang berisi pupa ditutup dengan wadah plastik yang beralas kasa. Pada bagian atas kasa diletakkan busa yang mengandung madu yang telah diencerkan. Setelah 5-7 hari, imago lalat buah dan parasitoid yang muncul dimatikan melalui proses pendinginan (Pusat Teknik dan Metoda Karantina Hewan dan Tumbuhan 2004). Metode pemeliharaan pada penelitian ini dilakukan di Balai Besar Karantina Pertanian Tanjung Priok, wilayah kerja Bogor.

\section{Pemasangan perangkap}

Metode pemasangan perangkap dilakukan dengan menggunakan perangkap Lynfield (IAEA 2003) yang dimodifikasi dengan memanfaatkan botol air mineral bekas. Bagian dinding botol dilubangi dengan diameter $5 \mathrm{~cm}$. Kemudian pada bagian dasar botol dilubangi dan digunakan untuk menggantungkan benang yang terikat dengan kapas yang berukuran $3 \mathrm{~cm}$. Kapas yang digantungkan ditetesi dengan atraktan dan pestisida dengan perbandingan 3:1.

Perangkap Lynfield diletakkan di bawah kanopi tanaman buah dengan tinggi 1,5 $\mathrm{m}$ dari permukaan tanah (Hasyim et al. 2006). Atraktan yang digunakan pada perangkap, yaitu metil 
Tabel 1. Lokasi administrasi serta lokasi geografi titik pengambilan sampel

\begin{tabular}{|c|c|c|c|c|c|}
\hline Kota/Kabupaten & Kecamatan & $\begin{array}{c}\text { Jumlah } \\
\text { desa }\end{array}$ & Lokasi geografi & $\begin{array}{c}\text { Ketinggian } \\
\text { (m dpl) }\end{array}$ & $\begin{array}{c}\text { Kategori } \\
\text { area }\end{array}$ \\
\hline \multirow[t]{6}{*}{ Kota Bogor } & Tanah Sareal & 3 & 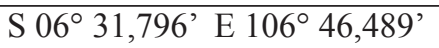 & 179 & Dataran bergelombang \\
\hline & Bogor Selatan & 2 & $\mathrm{~S} 06^{\circ} 36,372^{\prime}$ E $106^{\circ} 45,723^{\prime}$ & 336 & Dataran bergelombang \\
\hline & Bogor Tengah & 2 & $\mathrm{~S} 06^{\circ} 35,456^{\prime} \mathrm{E} 106^{\circ} 47,146^{\prime}$ & 251 & Dataran bergelombang \\
\hline & Bogor Barat & 2 & $\mathrm{~S} 06^{\circ} 33,281^{\prime} \mathrm{E} 106^{\circ} 45,108^{\prime}$ & 214 & Dataran bergelombang \\
\hline & Bogor Timur & 1 & $\mathrm{~S} 06^{\circ} 36,280^{\prime}$ E $106^{\circ} 49,143^{\prime}$ & 298 & Dataran bergelombang \\
\hline & Bogor Utara & 1 & $\mathrm{~S} 06^{\circ} 34,372^{\prime}$ E $106^{\circ} 49,348^{\prime}$ & 130 & Dataran bergelombang \\
\hline Kabupaten & Ciawi & 7 & $\mathrm{~S} 06^{\circ} 42,194^{\prime} \mathrm{E} 106^{\circ} 52,465^{\prime}$ & 637 & Dataran tinggi \\
\hline \multirow[t]{35}{*}{ Bogor } & Kemang & 3 & $\mathrm{~S} 06^{\circ} 31,930^{\prime} \mathrm{E} 106^{\circ} 45,255^{\prime}$ & 160 & Dataran bergelombang \\
\hline & Megamendung & 4 & $\mathrm{~S} 06^{\circ} 40,820^{\prime} \mathrm{E} 106^{\circ} 53,730^{\prime}$ & 715 & Dataran tinggi \\
\hline & Tamansari & 3 & $\mathrm{~S} 06^{\circ} 38,399^{\prime}$ E $106^{\circ} 46,448^{\prime}$ & 427 & Dataran bergelombang \\
\hline & Dramaga & 6 & $\mathrm{~S} 06^{\circ} 34,566^{\prime} \mathrm{E} 106^{\circ} 44,206^{\prime}$ & 208 & Dataran bergelombang \\
\hline & Tenjolaya & 2 & $\mathrm{~S} 06^{\circ} 39,761^{\prime} \mathrm{E} 106^{\circ} 43,191^{\prime}$ & 685 & Dataran tinggi \\
\hline & Cijeruk & 1 & $\mathrm{~S} 06^{\circ} 42,537^{\prime}$ E $106^{\circ} 47,661^{\prime}$ & 536 & Dataran tinggi \\
\hline & Bojong Gede & 2 & $\mathrm{~S} 06^{\circ} 31,963^{\prime}$ E $106^{\circ} 47,937^{\prime}$ & 189 & Dataran bergelombang \\
\hline & Ciampea & 2 & $\mathrm{~S} 06^{\circ} 33,459^{\prime} \mathrm{E} 106^{\circ} 41,721^{\prime}$ & 187 & Dataran bergelombang \\
\hline & Parung & 4 & $\mathrm{~S} 06^{\circ} 25,093^{\prime} \mathrm{E} 106^{\circ} 43,905^{\prime}$ & 113 & Dataran bergelombang \\
\hline & Rancabungur & 2 & $\mathrm{~S} 06^{\circ} 32,339^{\prime} \mathrm{E} 106^{\circ} 43,162^{\prime}$ & 171 & Dataran bergelombang \\
\hline & Cibungbulang & 2 & $\mathrm{~S} 06^{\circ} 35,136^{\prime} \mathrm{E} 106^{\circ} 39,726^{\prime}$ & 273 & Dataran bergelombang \\
\hline & Rumpin & 1 & S $06^{\circ} 27,558^{\prime}$ E $106^{\circ} 39,107^{\prime}$ & 102 & Dataran bergelombang \\
\hline & Ciseeng & 2 & S $06^{\circ} 26,619^{\prime}$ E $106^{\circ} 41,771^{\prime}$ & 130 & Dataran bergelombang \\
\hline & Cisarua & 1 & S $06^{\circ} 41,317^{\prime}$ E $106^{\circ} 56,000^{\prime}$ & 811 & Dataran tinggi \\
\hline & Ciomas & 1 & $\mathrm{~S} 06^{\circ} 36,130^{\prime} \mathrm{E} 106^{\circ} 46,248^{\prime}$ & 238 & Dataran bergelombang \\
\hline & Semplak & 1 & $\mathrm{~S} 06^{\circ} 31,520^{\prime} \mathrm{E} 106^{\circ} 45,824^{\prime}$ & 190 & Dataran bergelombang \\
\hline & Sukaraja & 2 & $\mathrm{~S} 06^{\circ} 35,157^{\prime}$ E $106^{\circ} 49,625^{\prime}$ & 130 & Dataran bergelombang \\
\hline & Babakan Madang & 2 & $\mathrm{~S} 06^{\circ} 35,472^{\prime} \mathrm{E} 106^{\circ} 52,749^{\prime}$ & 470 & Dataran bergelombang \\
\hline & Sukamakmur & 3 & $\mathrm{~S} 06^{\circ} 34,518^{\prime}$ E $106^{\circ} 57,234^{\prime}$ & 459 & Dataran bergelombang \\
\hline & Tajur Halang & 2 & $\mathrm{~S} 06^{\circ} 29,668^{\prime}$ E $106^{\circ} 46,111^{\prime}$ & 183 & Dataran bergelombang \\
\hline & Leuwisadeng & 1 & S $06^{\circ} 33,439^{\prime}$ E $106^{\circ} 37,548^{\prime}$ & 647 & Dataran tinggi \\
\hline & Leuwiliang & 1 & $\mathrm{~S} 06^{\circ} 37,030^{\prime} \mathrm{E} 106^{\circ} 37,881^{\prime}$ & 406 & Dataran bergelombang \\
\hline & Cileungsi & 1 & $\mathrm{~S} 06^{\circ} 22,401^{\prime} \mathrm{E} 106^{\circ} 58,951^{\prime}$ & 99 & Dataran rendah \\
\hline & Pamijahan & 4 & $\mathrm{~S} 06^{\circ} 48,005^{\prime} \mathrm{E} 107^{\circ} 12,005^{\prime}$ & 365 & Dataran bergelombang \\
\hline & Nanggung & 2 & $\mathrm{~S} 06^{\circ} 34,496^{\prime} \mathrm{E} 106^{\circ} 32,959^{\prime}$ & 298 & Dataran bergelombang \\
\hline & Cigudeg & 1 & $\mathrm{~S} 06^{\circ} 35,183^{\prime}$ E $106^{\circ} 32,659^{\prime}$ & 264 & Dataran bergelombang \\
\hline & Jasinga & 2 & S $06^{\circ} 27,963^{\prime}$ E $106^{\circ} 28,264^{\prime}$ & 251 & Dataran bergelombang \\
\hline & Sukajaya & 2 & $\mathrm{~S} 06^{\circ} 21,625^{\prime}$ E $106^{\circ} 31,164^{\prime}$ & 451 & Dataran bergelombang \\
\hline & Tenjo & 2 & $\mathrm{~S} 06^{\circ} 20,817^{\prime}$ E $106^{\circ} 30,219^{\prime}$ & 151 & Dataran bergelombang \\
\hline & Gn. Putri & 3 & S $06^{\circ} 26,748^{\prime}$ E $106^{\circ} 54,617^{\prime}$ & 139 & Dataran bergelombang \\
\hline & Klapanunggal & 1 & S $06^{\circ} 26,339^{\prime}$ E $106^{\circ} 57,120^{\prime}$ & 94 & Dataran rendah \\
\hline & Jonggol & 2 & $\mathrm{~S} 06^{\circ} 27,035^{\prime}$ E $107^{\circ} 03,587^{\prime}$ & 94 & Dataran rendah \\
\hline & Cariu & 1 & $\mathrm{~S} 06^{\circ} 30,627^{\prime} \mathrm{E} 107^{\circ} 07,728^{\prime}$ & 118 & Dataran bergelombang \\
\hline & Tanjungsari & 2 & $\mathrm{~S} 06^{\circ} 34,650^{\prime} \mathrm{E} 107^{\circ} 08,634^{\prime}$ & 122 & Dataran bergelombang \\
\hline & Gunung Sindur & 2 & $\mathrm{~S} 06^{\circ} 22,857^{\prime} \mathrm{E} 107^{\circ} 41,996^{\prime}$ & 98 & Dataran rendah \\
\hline Kabupaten & Setu & 1 & $\mathrm{~S} 06^{\circ} 21,164^{\prime} \mathrm{E} 107^{\circ} 01,295^{\prime}$ & 195 & Dataran bergelombang \\
\hline Bekasi & Cikarang timur & 1 & $\mathrm{~S} 06^{\circ} 18,931^{\prime} \mathrm{E} 107^{\circ} 03,644^{\prime}$ & 52 & Dataran rendah \\
\hline Kabupaten Depok & Beji & 1 & S $06^{\circ} 22,293^{\prime}$ E $106^{\circ} 47,924^{\prime}$ & 100 & Dataran rendah \\
\hline $\begin{array}{l}\text { Kabupaten } \\
\text { Cianjur }\end{array}$ & Karang tengah & 2 & S $06^{\circ} 48,005^{\prime}$ E $107^{\circ} 12,005^{\prime}$ & 1055 & Dataran tinggi \\
\hline
\end{tabular}

Dataran tinggi (501-1.000 m dpl); dataran bergelombang (101-500 m dpl); dan dataran rendah (50-100 m dpl). 


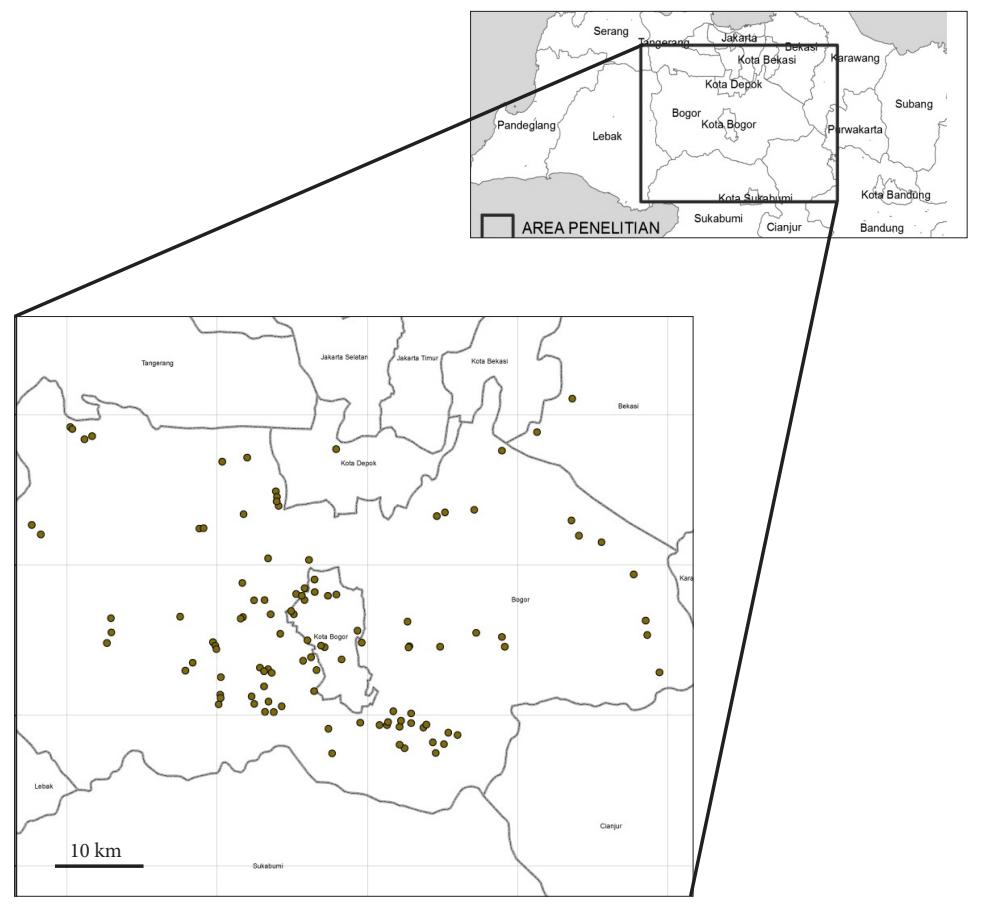

Gambar 1. Titik pengambilan contoh di Kabupaten Bogor dan sekitarnya (119 titik pengambilan contoh).

eugenol (ME) dan cue lure (CL) (IAEA 2003). Jumlah perangkap yang dipasang serta jarak antar perangkap berhubungan dengan keberadaan serta kuantitas inang lalat buah di lapangan yang digunakan sebagai dasar penggolongan tipe area penganbilan contoh. Tipe area pengambilan contoh lalat buah dibedakan menjadi habitat homogen dan habitat heterogen yang memiliki ketentuan jumlah pemasangan perangkap yang berbeda. Berdasarkan tipe atraktan yang digunakan, yaitu ME dan CL maka jarak perangkap yang diletakkan di lapangan berkisar antara $0.25-1 \mathrm{~km}$ per perangkap (IAEA 2003), sedangkan jarak antar perangkap dengan atraktan yang berbeda adalah $1 \mathrm{~m}$ (Shelly et al. 2004). Spesimen yang didapatkan kemudian dibawa ke Laboratorium Biosistematika Serangga, Institut Pertanian Bogor (IPB) untuk dikoleksi dan diidentifikasi.

\section{Identifikasi dan koleksi}

Imago lalat buah yang muncul pada metode pemeliharaan dan imago jantan yang didapatkan pada metode pemasangan perangkap dikoleksi dengan menggunakan balok poliporus, mikropin $(15 \mathrm{~mm})$ dan makropin $(39 \mathrm{~mm})$ dengan tipe 2 tahap penusukan (double pinning) (Gullan \& Cranston 2010). Imago lalat buah diidentifikasi dengan menggunakan CABI (2007) dan kunci identifikasi AQIS (2008). Semua spesimen yang didapatkan dan dikoleksi disimpan di Museum Serangga, Laboratorium Biosistematika Serangga, IPB.

\section{Analisis data}

Keanekaragaman spesies lalat buah dan inang dianalisis berdasarkan kategori dominasinya di berbagai area dengan ketinggian dan tipe habitat berbeda. Pengkategorian dominasi spesies lalat buah dengan cara membandingkan nilai dominansi (D) terhadap nilai frekuensi relatif (F) (Falcão de SÃ et al. 2012).

\section{HASIL}

\section{Keanekaragaman spesies lalat buah dari pe- rangkap atraktan dan pemeliharaan inang}

Berdasarkan hasil pemasangan perangkap dengan menggunakan atraktan ME dan CL yang diletakkan di area pengambilan sampel yang ditentukan, ditemukan 5 spesies lalat buah yang terperangkap ME dan 11 spesies yang terperangkap CL (Tabel 2). Rasio perbandingan jumlah spesies yang terperangkap ME dan CL yang ditemukan, yaitu $1: 2,2$. Spesies lalat buah yang paling banyak ditemukan adalah $B$. carambolae, sedangkan spesies lalat buah dengan jumlah individu terkecil adalah B. vulta, B. melastomatos, dan B. limbifera. 
Tabel 2. Jumlah individu dan kategori dominasi spesies lalat buah dari atraktan metil eugenol dan cue lure serta hasil pemeliharaan inang

\begin{tabular}{|c|c|c|c|c|}
\hline Spesies lalat buah & $\mathrm{N}$ & $\mathrm{F}$ & Nilai D & $\mathrm{D}$ \\
\hline \multicolumn{5}{|l|}{ Metil eugenol } \\
\hline B. (B.) carambolae & 1227 & 0,468 & 0,062 & $\mathrm{~d}$ \\
\hline B. (B.) papayae & 729 & 0,278 & 0,062 & $\mathrm{~d}$ \\
\hline B. (B.) umbrosa & 290 & 0,110 & 0,062 & d \\
\hline B. (B.) verbascifoliae & 12 & 0,004 & 0,062 & nd \\
\hline B. (B.) occipitalis & 3 & 0,001 & 0,062 & nd \\
\hline Total individu & 2261 & & & \\
\hline \multicolumn{5}{|l|}{ Cue lure } \\
\hline B. (Z.) cucurbitae & 121 & 0,046 & 0,062 & nd \\
\hline B. (Z.) calumniata & 63 & 0,024 & 0,062 & nd \\
\hline B. (B.) albistrigata & 113 & 0,043 & 0,062 & nd \\
\hline B. (Z.) vulta & 1 & 0,0004 & 0,062 & nd \\
\hline B. (B.) usitata & 15 & 0,005 & 0,062 & nd \\
\hline B. (B.) limbifera & 1 & 0,0003 & 0,062 & nd \\
\hline B. (Z.) caudata & 29 & 0,011 & 0,062 & nd \\
\hline B. (Z.) tau & 4 & 0,001 & 0,062 & nd \\
\hline B. (B.) mollucensis & 6 & 0,002 & 0,062 & nd \\
\hline B. (B.) melastomatos & 1 & 0,0003 & 0,062 & nd \\
\hline D. (C.) longicornis & 6 & 0,002 & 0,062 & nd \\
\hline Total individu & 360 & & & \\
\hline \multicolumn{5}{|l|}{ Pemeliharaan inang } \\
\hline B. (B.) latifrons & & & & \\
\hline B. (Bu.) megregori & & & & \\
\hline
\end{tabular}

N: total individu; F: frekuensi relatif; D: 1/seluruh spesies (dominansi) (Falcão de SÃ et al. 2012); F>D (d: dominan); F<D (nd: non dominan); B (B): Bactrocera Bactrocera; B (Z): Bactrocera Zeugodacus; D (C): Dacus Callantra; B (Bu.): Bactrocera Bulladacus.

Keanekaragaman dan persebaran lalat buah pada berbagai habitat di Kabupaten Bogor dan sekitarnya

Hasil pemasangan perangkap tidak hanya memberikan informasi terkait jumlah individu, namun juga memberikan gambaran mengenai persebaran spesies lalat buah. Lalat buah ditemukan di hampir seluruh wilayah Kabupaten Bogor dan beberapa wilayah di Kabupaten Depok, Bekasi dan Cianjur. Spesies lalat buah yang paling dominan ditemukan di setiap titik sampling adalah B. carambola dan B. papayae baik menggunakan metode pemasangan perangkap maupun pemeliharaan inang. Selain itu, terdapat beberapa spesies lalat buah, seperti B. latifrons dan B. mcgregori yang hanya bisa didapatkan dengan metode pemeliharaan inang tertentu sehingga persebarannya sangat dipengaruhi oleh keberadaan inangnya di suatu wilayah. Spesies lalat buah lainnya umumnya ditemukan pada habitat tertentu, seperti $B$. vulta, B.limbifera, $B$. usitata, B. mollucensis dan B. melastomatos yang hanya ditemukan pada habitat hutan.
Lalat buah tidak hanya ditemukan pada tipe habitat yang beragam, tetapi juga ditemukan pada area dengan ketinggian yang berbeda. Berdasarkan hasil pengambilan sampel yang dilakukan di tiga kelompok wilayah dengan ketinggian yang berbeda serta kategori tipe habitat yang berbeda, ditemukan bahwa jumlah spesies dan individu lalat buah tertinggi ditemukan pada daerah dataran sedang. Dataran rendah dan dataran tinggi memiliki keanekaragaman spesies lalat buah serta persentase individu yang rendah (Gambar 2). Selain dengan melakukan pemasangan perangkap, keberadaan lalat buah juga dapat diketahui dengan melakukan pemeliharaan inang. Berdasarkan hasil pemeliharaan inang lalat buah yang dilakukan, ditemukan 7 spesies lalat buah yang berperan sebagai hama pada 22 spesies tanaman hortikultura dan 2 spesies tanaman hutan yang termasuk ke dalam 14 famili (Tabel 3).

\section{PEMBAHASAN}

Berdasarkan hasil pemasangan perangkap, CL merupakan atraktan yang diketahui dapat menarik 


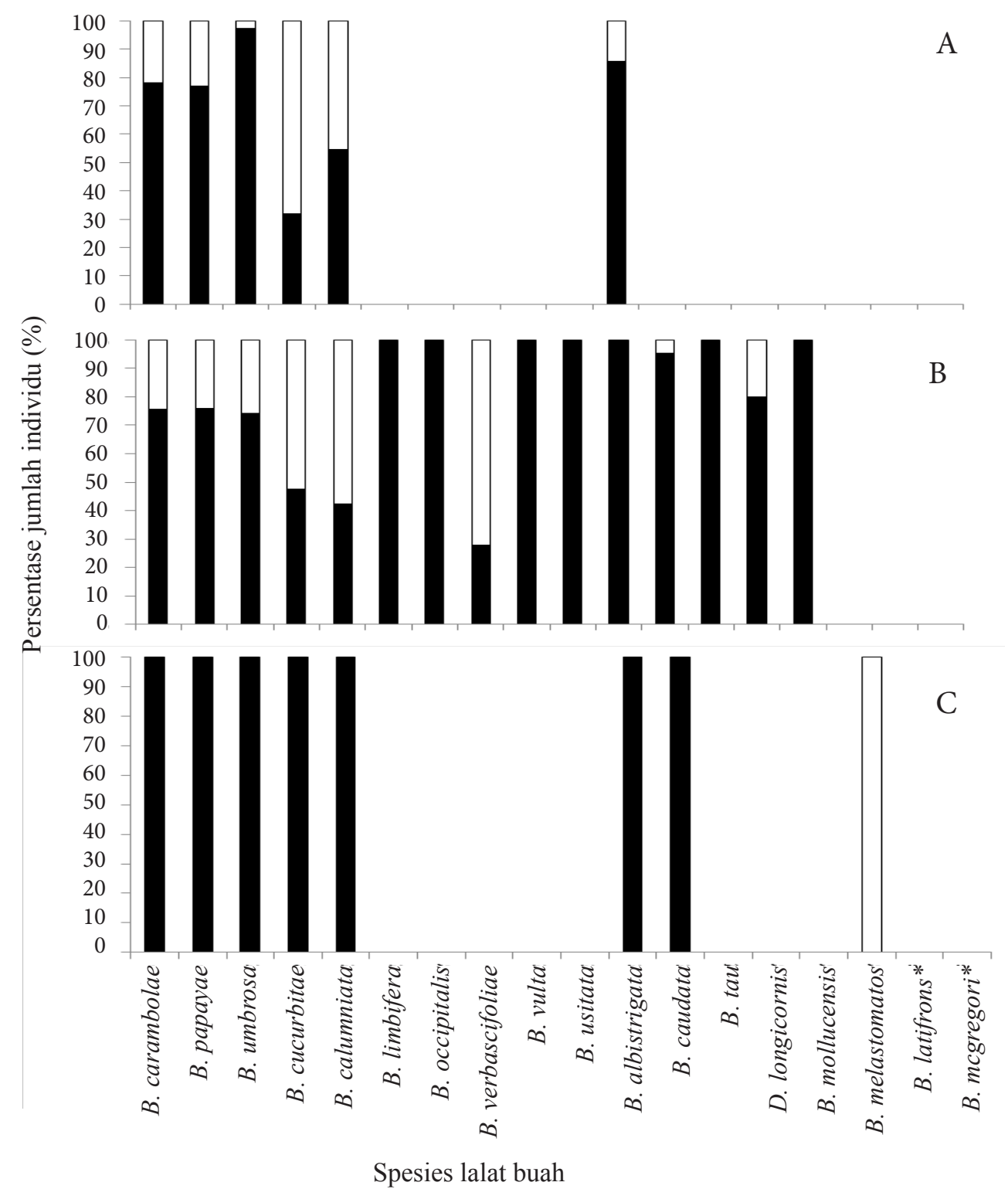

Gambar 2. Persentase dan jumlah spesies lalat buah pada habitat heterogen dan homogen di dataran: A: tinggi ( $>500 \mathrm{~m} \mathrm{dpl})$; B: dataran sedang $(100-500 \mathrm{~m} \mathrm{dpl})$; dan C: dataran rendah $(<100 \mathrm{~m} \mathrm{dpl})$ (keterangan: * hasil pemeliharaan inang; habitat homogen $(\square)$; habitat heterogen ( $\square$ ).

lebih banyak spesies lalat buah dibandingkan dengan ME. Hasil yang sama didapatkan pada penelitian yang dilakukan Tsuruta et al. (2005), yang menunjukkan tingginya jumlah spesies lalat buah yang didapatkan menggunakan atraktan CL. CL umumnya dapat digunakan untuk menarik beberapa spesies lalat buah yang berperan sebagai hama. Namun, sebagian besar jenis lalat buah yang tertarik oleh atraktan ini merupakan spesies lalat buah hutan yang terkategori sebagai spesies non dominan dikarenakan memiliki jumlah individu serta sebaran lokasi yang sangat terbatas. Menurut Ginting (2009), struktur vegetasi serta keberadaan inang juga dapat menyebabkan keterbatasan 56 jumlah individu serta wilayah sebaran dari spesies non dominan. Inang lalat buah tidak hanya mempengaruhi persebaran lalat buah di Kabupaten Bogor dan sekitarnya, namun juga menyebabkan adanya perbedaan kelompok lalat buah.

Perbedaan kelompok lalat buah berdasarkan kisaran inang pada spesies lalat buah dapat terjadi akibat proses koevolusi yang terjadi antara spesies lalat buah dan inangnya. Perbedaan kisaran inang yang dimiliki oleh spesies lalat buah dipengaruhi oleh preferensi serta persepsi lalat buah terhadap morfologi, nutrisi, persebaran dan kuantitas tanaman inang serta interaksi terhadap organisme serta individu lain (Bernays \& Chapman 1994). 
Tabel 3. Famili dan spesies inang lalat buah yang berasosiasi dengan spesies lalat buah di Kabupaten Bogor dan sekitarnya

\begin{tabular}{|c|c|c|c|c|c|c|c|c|c|c|}
\hline \multirow{2}{*}{ Famili } & \multirow{2}{*}{ Spesies inang } & \multirow{2}{*}{$\begin{array}{l}\text { Nama umum } \\
\text { inang }\end{array}$} & \multicolumn{8}{|c|}{ Spesies lalat buah } \\
\hline & & & Bcr & Bpp & Bcc & $\mathrm{Bcl}$ & Blt & $\mathrm{Bab}$ & Bmg & Bub \\
\hline \multirow[t]{2}{*}{ Myrtaceae } & Syzigium aqueum & Jambu air & + & + & & & & + & & \\
\hline & Psidium guajava & Jambu biji & + & + & & & & + & & \\
\hline \multirow[t]{2}{*}{ Averrhoaceae } & Averrhoa carambolae & Belimbing & + & + & & & & + & & \\
\hline & Averrhoa bilimbi & Belimbing wuluh & + & & & & & & & \\
\hline \multirow[t]{4}{*}{ Solanaceae } & Capsicum annum & Cabai & + & + & & & & & & \\
\hline & Capsicum frustescens & Cabai rawit & + & + & & & & & & \\
\hline & Solanum melongena & Terung & & + & & & + & & & \\
\hline & Solanum lycopersicum & Tomat & & + & & & + & & & \\
\hline \multirow[t]{2}{*}{ Anacardiaceae } & Mangifera indica & Mangga & + & + & & & & & & \\
\hline & Bouea macrophylla & Gandaria & & + & & & & & & \\
\hline \multirow[t]{2}{*}{ Rutaceae } & Citrus amblycarpa & Jeruk hias & & + & & & & & & \\
\hline & Citrus reticulata & Jeruk manis & + & + & & & & & & \\
\hline \multirow[t]{3}{*}{ Cucurbitaceae } & Cucumis sativus & Mentimun & & & + & + & & & & \\
\hline & Momordica charantia & Paria & & & + & + & & & & \\
\hline & Luffa cylindrica & Oyong & & & + & + & & & & \\
\hline Caricaceae & Carica papayae & Pepaya & & & & + & & & & \\
\hline Lauraceae & Persea americana & Alpukat & & + & & & & & & \\
\hline \multirow[t]{2}{*}{ Moraceae } & Artocarpus integer & Cempedak & & & & & & & & + \\
\hline & Artocarpus heterophyllus & Nangka & & & & & & & + & \\
\hline Gnetaceae & Gnetum gnemon & Melinjo & & & & & & & + & \\
\hline Meliaceae & Sandoricum coetjape & Kecapi & & + & & & & & & \\
\hline Thymelaeceae & Phaleria macrocarpa & Mahkota dewa & + & & & & & & & \\
\hline Melastomaceae & Melastoma affine & Harendong & + & & & & & & & \\
\hline \multirow[t]{3}{*}{ Gmelinaceae } & Gmelina arborea & Gmelina & + & & & & & & & \\
\hline & Total famili & & 8 & 7 & 1 & 2 & 1 & 2 & 1 & 1 \\
\hline & Total spesies & & 10 & 13 & 3 & 4 & 2 & 2 & 1 & 2 \\
\hline
\end{tabular}

Bcr: B. carambolae; Bpp: B. papayae; Bcc: B. cucurbitae; Bcl: B. calumniata; Blt: B. latifrons; Bab: B. albistrigata; Bmg: B. mcgregori; Bub: B. umbrosa.

Interaksi yang terjadi antara lalat buah dan inangnya juga dipengaruhi oleh proses koevolusi yang dapat mempengaruhi perilaku serta sistem fisiologi lalat buah. Schoonhoven et al. (2005) menyatakan bahwa evolusi pada sistem kemosensori dapat berpengaruh terhadap sensitifitas spesies lalat buah terhadap inangnya.

$B$. carambolae dan B. papayae merupakan spesies lalat buah polifag yang mampu menyerang inang dengan jumlah tertinggi. Jenis inang yang terserang tidak hanya berasal dari tanaman hortikultura, namun juga tanaman hutan, seperti Gmelina sp. dan Melastoma sp. Tanaman hutan umumnya bukan merupakan inang utama dari spesies ini, namun keberadaan tanaman hutan di suatu habitat dapat berperan sebagai inang alternatif bagi lalat buah di suatu habitat, pada saat keberadaan inang utama mulai langka (Harris et al. 2003).

Inang yang berasosiasi dengan spesies lalat buah terbanyak adalah Psidium guajava, Syzigium aqueum dan Averrhoa carambolae yang diketahui berperan sebagai inang utama bagi berbagai macam spesies lalat buah (Allwood et al. 1998). Inang yang hanya dapat berasosiasi dengan 1 spesies lalat buah adalah Gnetum gnemon yang berkaitan erat dengan keberadaan B. mcgregori di suatu habitat. Informasi lain yang ditampilkan pada Tabel 2, yaitu terdapat penambahan kisaran inang yang dimiki oleh $B$. calumniata. Spesies lalat buah ini ditemukan dapat menyerang tanaman pepaya (Caricaceae) yang belum pernah dilaporkan sebelumnya.

Spesifisitas inang yang dimiliki oleh spesies lalat buah yang ditemukan dapat membentuk suatu struktur atau kumpulan asosiasi lalat buahinang yang terpisah dan secara tidak langsung dapat memperkaya dan menjaga kestabilan keanekaragaman spesies lalat buah di suatu wilayah (Novotny et al. 2005).

Dataran sedang yang terdapat di Kabupaten Bogor umumnya terdiri atas berbagai tipe 
habitat dan area budi daya tanaman hortikultura. Berdasarkan jumlah jenis inang dan tipe habitat, wilayah ini memiliki peran, seperti habitat heterogen yang menyebabkan tingginya jumlah spesies lalat buah yang ditemukan di dataran sedang. Selain itu, tingginya persentase wilayah dataran sedang di Kabupaten bogor juga berpengaruh terhadap tingginya jenis spesies dan jumlah individu lalat buah yang didapatkan. Liu et al. (2005) menyatakan bahwa lalat buah umumnya banyak ditemukan di wilayah dengan ketinggian $<1500 \mathrm{~m}$ dpl, khususnya pada dataran sedang dan rendah. Daerah dataran tinggi secara umum didominasi oleh hutan alami dan pertanaman sayuran yang merupakan tanaman inang dari spesies lalat buah tertentu, seperti $B$. carambolae, $B$. papayae, B. calumniata, B. cucurbitae, $B$. albistrigata dan $B$. umbrosa. Minimnya keanekaragaman jenis tanaman inang juga ditemukan pada daerah dataran rendah. Kondisi ini menyebabkan terjadinya keterbatasan jumlah spesies dan individu lalat buah di daerah dataran rendah dan dataran tinggi.

Berdasarkan jenis inang, habitat heterogen di dataran tinggi, sedang dan rendah memiliki jenis inang lebih tinggi dibandingkan dengan habitat homogen. Tingginya jenis inang yang terdapat pada habitat heterogen dapat membentuk suatu lingkungan yang kondusif bagi berbagai spesies lalat buah. Harris et al. (2001) menyatakan bahwa keanekaragaman inang yang tinggi sangat mempengaruhi keanekargaman spesies, kelimpahan individu dan persebaran lalat buah di suatu wilayah, sedangkan habitat homogen umumnya terdiri atas inang dengan jenis yang terbatas sehingga menyebabkan adanya keterbatasan spesies lalat buah yang terdapat pada wilayah tersebut. Penelitian yang dilakukan oleh Vayssiéres et al. (2009), menunjukkan bahwa keberadaan tanaman yang sengaja dibudidayakan dalam jumlah tinggi sangat mempengaruhi populasi spesies lalat buah yang menjadi hama tanaman tersebut.

\section{KESIMPULAN}

Keanekaragaman spesies lalat buah yang ditemukan di Kabupaten Bogor dan sekitarnya adalah 18 spesies. B. latifrons merupakan spesies lalat buah yang sebelumnya belum pernah ditemukan di Kabupaten Bogor. B. carambolae, $B$. papayae dan B. umbrosa merupakan spesiesspesies yang paling umum ditemukan di seluruh titik pengambilan contoh. Keberadaan dan keanekaragaman spesies lalat buah di Kabupaten Bogor dan sekitarnya dipengaruhi oleh pola persebaran dari inangnya. Beberapa spesies lalat buah diketahui bersifat non dominan dan hanya ditemukan di habitat dengan jenis vegetasi tertentu.

\section{DAFTAR PUSTAKA}

Allwood AJ, Kritsaneepaiboon S, Chinajariyawong A, Drew RAI, Hancock EL, Hengsawad C, Jipanin JC, Jirasurat M, Krong CK. 1998. Host plant records for fruit flies (Diptera: Tephritidae) in Southeast Asia. Raffles Bulletin of Zoology 47:1-92.

[AQIS] Australian Quarantine and Inspection Service. 2008. Fruit Flies Indonesia: Their Identification. Pest Status dan Pest Management. Conducted by the international center for the management of pest fruit flies. Canberra: Griffith University, Brisbane Australia and ministry of Agriculture, Republic of Indonesia.

Bernays EA, Chapman RF. 1994. Host-Plant Selection by Phytophagous Insects. New York: Chapman and Hall Publishing.

Drew RAI. 2004. Biogeography and speciation in the Dacini (Diptera: Tephritidae: Dacinae). Bishop Museum Bulletin in Entomology 12:165-178.

[CABI] Center in Agricultural and Biological Institute. 2007. Crop Protection Compendium (CD-ROM). Wallingford: CAB International.

Falcão de SÃ R, Castellani MA, Ribeiro AEL, Perez-Maluf R, Moreira AA, Nagamoto NS, do Nascimento AS. 2012. Faunal analysis of the species Anastrepha in the fruit growing complex Gavião River, Bahia, Brazil. Bulletin of Insectology 65:37-42.

Ginting R. 2009. Keanekaragaman Lalat Buah (Diptera: Tephritidae) di Jakarta, Depok, dan Bogor Sebagai Bahan Kajian Penyusunan Analisis Risiko Hama. MS Thesis. Bogor: Institut Pertanian Bogor.

Gullan PJ, Cranston PS. 2010. The Insects: an Outline of Entomology. United States: WileyBlackwell Publishing.

Harris EJ, Liquido NJ, Lee CYL. 2003. Patterns in appearance and fruit host utilization of fruit flies (Diptera: Tephritidae) on the Kalaupapa 
Peninsula, Molokai Hawaii. Proceedings Hawaiian Entomology Society 36:69-78.

Harris EJ, Liquido NJ, Lee Spencer JP, 2001. Distribution and host utilization of Bactrocera latifrons (Diptera: Tephritidae) on the Island. Hawaii. Proceedings Hawaiian Entomol Society 35:55-66.

Hasyim A, Muryati, De Kogel WJ. 2006. Efektifitas model dan ketinggian perangkap dalam menangkap lalat buah jantan. Bactrocera spp. Jurnal Hortikultura 16:314-320.

[IAEA] International Atomic Energy Agency. 2003. Trapping Guidelines for Area-Wide Fruit Fly Programmes. Vienna: Austria.

Kartini L, Trisnasari, Heriyenti, Juhariyono, Komaruddin. 2003. Laporan Ujicoba Perlakuan Karantina. Palembang: Balai Karantina Tumbuhan Boom Baru Palembang.

Liu XF, Wang DM, Ye H. 2005. Overview on Research of Bactrocera correcta (Bezzi) in Yunnan. Thesis. Yunan: Yunnan University.

Nishida T. 1980. Food System of Tephritid Fruit Flies in Hawaii. Hawai: University of Hawaii.

Novotny V, Clarke AR, Drew RAI, Balagawi S, Clifford B. 2005. Host specialization and species richness of fruit flies in New Guinea Rain Forest. Journal of Tropical Ecology 21:67-77. doi: http://dx.doi.org/10.1017/S0266467404002044.

Pusat Teknik dan Metoda Karantina Hewan dan Tumbuhan. 2004. Petunjuk Teknis Surveilan Lalat Buah. Badan Karantina Pertanian.
Schoonhoven LM, Van Loon JJA, Dicke M. 2005. Insect Plant Biology. England: Oxford publishing.

Shelly TE, Pahio E, Edu J. 2004. Synergistic and inhibitory interactions between methyl eugenol and cue lure influence trap catch of male fruit flies, Bactrocera dorsalis (Hendel) and $B$. cucurbitae (Diptera: Tephritidae). Florida Entomologist 87:481-486. doi: http://dx.doi. org/10.1653/0015-4040(2004)087[0481:SAIIB $\mathrm{M}] 2.0 . \mathrm{CO} ; 2$.

Siwi SS, Hidayat P, Suputa. 2006. Taksonomi dan Bioekologi Lalat Buah Penting di Indonesia (Diptera: Tephritidae). Bogor: Balai Besar Penelitian dan Pengembangan Bioteknologi dan Sumberdaya Genetik Pertanian.

Tsuruta K, Bandara HMJ, Rajapakse GBJP. 2005. Notes on the lure responsiveness of fruit flies of the Tribe Dacini (Diptera: Tephritidae) in Sri Lanka. Esakia 45:179-184.

Vayssiéres JF, Korie S, Ayegnon D. 2009. Correlation of fruit fly (Diptera: Tephritidae) infestation of major mango cultivars in Borgou (Benin) with abiotic and biotic factors and assessment of damage. Crop Protection 28:477-488. doi: http:// dx.doi.org/10.1016/j.cropro.2009.01.010. 